\title{
A modified light weight piston corer for sampling soft lake sediment
}

\author{
D.J. Douglas 1
}

Keywords : Methods, corer, sediments.

A modified version of the light weight * Murray " piston corer is described. This corer may be used in any depth of water and is particularly suited to loose unconsolidated sediment. The new design overcomes some of the problems inherent in the earlier model.

Modficication d'un carottier à piston allégé destiné à prélever les sédiments meubles des lacs.

Mots clés : Méthodes, carottier, sédiments.

Une version modifiée du carottier à piston allégé * Murray " est décrite. Ce carottier peut être utilisé à toutes les profondeurs et convient particulièrement pour les sédiments très meubles. Le nouveau modèle surmonte les problèmes inhérents au modèle antérieur.

In order to obtain undisturbed sedimentary cores of soft subaequeous deposits in Irish lakes, a corer was designed which combined the advantages of light weight and one man operation (Murray 1976). The main innovation is the use of strong elastic cord rubber to propel the core tube into the sediment. Two lenghts of cord rubber are at tached to hooks on the bot tom of the coring head, stretched around pulleys on the base plate and tensioned by ropes attached to hooks on the top plate. A triggering device on the top platc is activated by means of a messenger weight. This corer has been used successfully in a number of paleolimnological studies (Murray \& Douglas 1977, Douglas et al. 1978, Douglas \& Murray 1987). The corer has been operated successfully in water depths to $75 \mathrm{~m}$. There is no reason to suppose that operation would not be equally successful in deeper water. However, a number of disadvantages are apparen in the original design. The present modified design overcomes these

1. Dept. of Experimental Sciences, Regional Technical College. Dundalk, Co. Louth. Ireland. shortcomings. The main disadvantages of the Murray corer may be listed as follows :

1. It is necessary during operation to lower the corer right to the sediment surface until a slackening in tension is noticed in the lowering rope. The corer must then be raised and moved to the side before triggering. This is largely a matter of practice and skill but has the inherent disadvantage of causing disturbance to the core site.

2 . If the bottom sediment is very soft then it is difficult to determine the "true "bottom because the corer easily sinks in to the mud/water interface which provides little resistance and hence no slackening in tension of the lowering rope.

3. The fact that the corer must be held suspended over the bottom can cause problems in obtaining vertical core samples - particularly if there is some surface drift as can occur over deep water even with the boat firmly anchored. This problem can be extremely difficult to detect if the sediments are unlayered.

4. The friction caused by the movement of the coring head down the guide rods impairs coring 
efficiency. Unless rigid nylon or high quality stainless steel is used for the guide rods, rust can be a problem, reducing coring efficiency.

The design parameters for corers for one man operation from a trailer carried rowing boat dictate that the overall weight should not exceed $20 \mathrm{~kg}$ (Hakanson \& Jansson 1983). This obviously limits the type of materials that can be employed in corer manufacture. However, proper choice of materials will allow corers capable of taking cores $2.0 \mathrm{~m}$ long to be constructed. While the basis of the originial design of Murray (loc. cit) has been retained, the following modifications have been incorporated to overcome weaknesses in the original design :

a) The top plate consists of a piece of stainless steel $(18 \mathrm{~cm} \times 4 \mathrm{~cm} \times 0,6 \mathrm{~cm})$ and a wooden block $(4 \mathrm{~cm} \times 18 \mathrm{~cm} \times 2,5 \mathrm{~cm})$. The addition of wood in this position gives the corer a slight amount of positive buoyancy. The top plate is drilled to accept the guide rods and the piston rod. The guide rods also provide points of attachment for the triggering device. Two extra holes $(8 \mathrm{~mm})$ are drilled at either end of the top plate to accept 4 hooks. These hooks serve for attachment of the tensioning ropes attached to the cord rubber. A safety rope attached to the coring head can be slipped over one of thesc hooks to prevent premature accidental firing of the corer.

b) The coring head design has been changed. This now consists of a mild steel plate $(17,5 \mathrm{~cm} \times 7,5 \mathrm{~cm}$ $\times 1,0 \mathrm{~cm}$ ) onto which is welded a mild steel cylindrical housing $(60 \mathrm{~cm}$ external diameter, $40 \mathrm{~cm}$ long). The inner diameter of the core housing is dril. led to the diameter of the core tube being used. The top of the core tube and the inner surface of the core tube housing are threaded to allow easy attachment. Two holes are drilled in the head plate to accommodate the guide rods. Brass bushings are inserted into these holes to minimise friction as the head travels Jown the guide rods. Four additional holes $(8 \mathrm{~mm}$ liameter) are drilled in the head plate to accept hooks for the at tachment of the triggering release cords and the cord rubber which drives the core tube into the sediment. Lead bars drilled to accommodate these hooks can be added if desired to increase the weight of the head (fig. 1).

c) The guide rods are manufactured from $20 \mathrm{~mm}$ diameter stainless steel rod cut to the desired length this depends on the maximum length of core

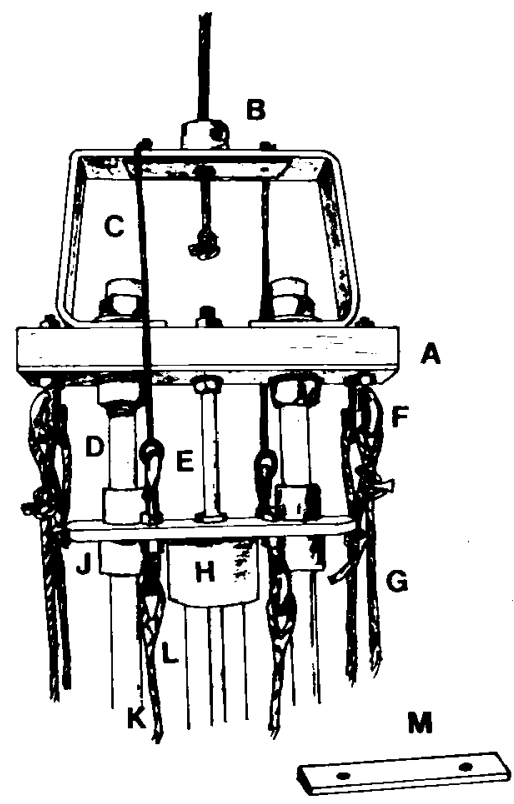

Fig. 1 : Detail of the top of the corer (A) Top plate (B) Trigger (C) Trigger release cord (D) Guide rod (E) Piston rod (F) Hooks for tensioning ropes (G) Tensioning rope $(\mathrm{H})$ Coring head $(\mathrm{J})$ Brass bushing (K) Cord rubber (L) Core iube - preferably transparent (perspex) so that the unextruded core can be photographed (M) Additional lead weight for attachment to the head.

desired) and threaded at both ends for attachment to the top and bot tom plates. The piston rod is manufactured out of $10 \mathrm{~mm}$ diameter stainless steel rod and threaded at both ends for at tachment to the top plate and for at tachment of the piston. The use of stainless steel increases the weight of the corer but this is compensated for by increased coring efficiency.

d) Spring loaded stop pads are attached to the bottom of the guide rods to protect the pulleys and to gradually arrest the head. 


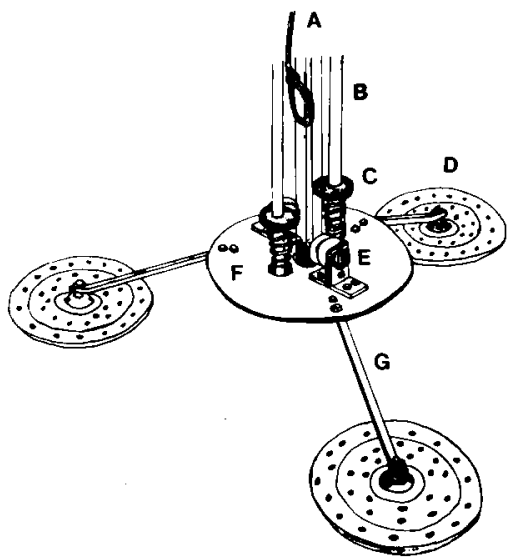

Fig. 2 : Detail of the bot tom of the corer. (A) Cord rubber before being stretched around the pulley (B) Guide rod (C) Stop pad and spring buffer (D) Foot (E) Pulley (F) Bottom plate (G) Leg.

c) The pullevs are manufactured out of nylon and bolted to the bottom plate. This overcomes the problems associated with metal pulleys and obviates the need for wooden blocks under the bottom plate thus eliminating the small amount of positive buoyancy they caused.

f) The bot tom plate has been enlarged. It consists of mild steel ( $30 \mathrm{~cm}$ diameter $\& 0,6 \mathrm{~cm}$ thick). Holes are drilled to accept the guide rods and a central aperture cut out slightly larger than the extemal diameter of the core tube. The pulleys are bolted onto the bottom plate at right angles to the guide rods.

g) Three legs have been added to the base plate raising the corer $20 \mathrm{~cm}$ above the sediment surface. These legs consist of $1,25 \mathrm{~cm}$ thick stainless steel bars bent to $20^{\circ}$. The legs are spaced at $120^{\circ}$ around the base plate and are angled to ensure that the whole structure stands level. On the ends of the legs are three swivel ball joints secured by nuts. Attached to the ball joints are the "feet ". These consist of flat discs (frisbees) which are drilled with holes to minimise the formation of "bow-waves " during descent (fig. 2). The feet operate on the snowshoe principle spreading the weight of the sampler on soft sediments and minimise sinking into the sediment. The swivel joints have a $30^{\circ}$ movement which aids vertical coring on uneven surfaces. An added advantage of the feet is that they allow easy determination of the bottom as the tension comes off the rope. Because the base of the corer is held $20 \mathrm{~cm}$ (or more depending on the length of the legs) above the bottom, the mud/water interface is always sampled intact. In slightly harder sediments the feet have the advantage of reducing the recoil described by Murray (loc. cit.).

The types of core tubes that have been used with this corer have been $1,5 \mathrm{~m}$ long and 3,5 to $5,0 \mathrm{~cm}$ in diameter. Hakanson \& Jansson (loc. cit.) have pointed out that if the inner diameter of tubes that are open at the bottom exceeds $5,0 \mathrm{~cm}$, very loose sediment may be lost during retrieval. For this reason it is felt that tubes with diameters in excess of $5 \mathrm{~cm}$ should not be used with this type of corer. However, this creates another problem in that Hvorslev (1949) recommended that the cross-sectional area of the walls of core tubes should be less than $10 \%$ of the sample area. With small diameter core tubes the walls become too thin to allow efficient coring if this criterion is to be met. For example, with the sample area provided by a $3,5 \mathrm{~cm}$ diameter tube, the walls could only be $0,85 \mathrm{~mm}$ thick. This would make it impossible to thread the outside of the core tube and would cause the tube to flex and break in consolidated sediments. Walls of a least $2 \mathrm{~mm}$ thick are necessary for core tube rigidity and threading. Grinding down the cutting edge of the core tube facilitates penetration and allows the cross-sectional areas to come close to the Hvorslev ratio.

The components of the corer manufactured out of mild steel must be treated to prevent corrosion. If weight is at a premium then the corer could easily be made from nylon which is both light and corrosive resistant. However, this increases the cost of manufacture considerably.

\section{References}

Douglas (D. J.), Murray (D.A.), Halliday (M.) \& Greene (J.). 1978. Correlation between exchangable phosphorus and sedimentary pigment in some Irish lakes. Verh. Intemat. Verein. Limmol., $20: 618-623$.

Douglas (D.J.) \& Murray (D.A.). 1987, - Paleolimnological Studies of Irish Iakes 1 : Lough Leane, Killarney, Co. Kerry. Irish Journal of Environmental Science IV. $\mathrm{N}^{\circ} 2: 33.41$. 
Hakanson (L.) \& Jansson (M.). 1983. - Principles of Lake Sedimentology. Springer Verlag.

H vorslev (M.J.). 1949. - Subsurface exploration and sampling of soils for civil engineering purposes. U.S. Army Corps. Eng. Waterways Exp. Stn., Vicksburg. Miss. 521 pp.
Murray (D.A.). 1976. - A light weight corer for sampling subaqueous deposits. Lininol. Oceartogr. $21: 341-344$.

Murray (D.A.) \& Douglas (D.J.). 1977. - Eutrophication : Past, Present and Future. In $\propto$ Lake Pollution Prevention by Eutrophication Control ». Ed. W.K. Downey and G. Ni Uid Stationary Office, Dublin : pp. 86-95. 